\title{
Oyuncunun Sanatı Olarak Aksiyon Yaratmak: Stanislavski, Brecht, Grotowski*
}

\section{Creating Action as Actor's Art: Stanislavski, Brecht, Grotowski}

Şebnem Sözer Özdemir, Sahne Sanatları Bölümü, Düzce Üniversitesi

\section{Özet}

Aksiyon kavramı 20. yüzyıldan itibaren Batılı tiyatro kuramları içinde oyuncunun sanatı üzerine geliştirilen düşünceler içinde önemli bir yer tutmaktadır. Farklı tiyatro uygulamacıları/kuramcllarının bu kavrama getirdiği yeni yorumlar onlara ait kendine özgü tiyatro ve oyunculuk anlayışlarına biçim vermiştir. Bu makale oyuncunun sanatının her şeyden önce aksiyon(lar) yaratmak olduğu fikrini temel alarak, 20. yüzyılda yaşamış üç önemli tiyatro insanı olan Konstantin Stanislavski, Bertolt Brecht ve Jerzy Grotowski'nin aksiyon kavramına yaklaşımlarının ne olduğunu karşılaştırmalı olarak incelemektedir. Amaç bu üç sanatçının her birine ait özgün oyunculuk anlayıșının daha derinlikli bir şekilde kavranmasını sağlamaktır. Bu bağlamda Stanislavski'nin geliștirdiği fiziksel aksiyon, Brecht'in karakterin aksiyonuna eklenmesini istediği oyuncu aksiyonu ve Grotowski'nin savunduğu literal aksiyon kavramlarına yakından bakılarak aralarındaki benzerlik ve farklılıklar tartışılmıştır. Sonuçta bu üç yaklaşımın hepsinde oyuncunun sanatının itkilerin keşfi aracılığıyla aksiyonlar yaratmak olarak kabul edildiği ortaya konmuştur. Bununla birlikte, Stanislavski karakterin itkilerinin keşfi aracılığıyla oyuncunun fiziksel aksiyon çizgisinin oluşturmasına odaklanmakta, Brecht karakterin itkileri yanında oyuncunun karakterin aksiyonlarına karşı geliştireceği tavrın da keșfedilmesi gereğini savunmakta, Grotowski ise oyuncuyu gündelik yaşamın dişına taşıyan ve ona bir insan olarak gelişiminde yol gösteren özel aksiyonların ortaya çıkmasına yol açacak itkilerin peşine düşmektedir.

Anahtar Sözcükler: Oyunculuk, aksiyon, Stanislavski, Brecht, Grotowski.

Akademik disipin(ler)/alan(lar): Oyunculuk kuramı, tiyatro kuramı.

\begin{abstract}
In Western theatre theories starting from the 20th century, the concept of action has occupied an important place within the thoughts that have been developed on the actor's art. New interpretations of this concept by different theatre practitioners/theorists have shaped their distinctive understandings of theatre and acting. Based on the idea that the actor's art is primarily creating action(s), this article investigates comparatively how Konstantin Stanislavski, Bertolt Brecht and Jerzy Grotowski, three important theatre people of the 20th century, have approached the concept of action. The purpose is to provide a deeper comprehension of the specific understandings of acting that belong to these three artists. In this context, the article explores the concepts of physical action as developed by Stanislavski, actor's action that Brecht wished to add to the character's action, and the concept of literal action as argued by Grotowski, while it discusses the similarities and differences between them. In conclusion, the article puts forward that in all these three approaches, the actor's art has been considered as creating actions by discovering impulses. Nevertheless, Stanislavski focuses on the formation of the series of physical actions through discovering character's impulses, Brecht defends the necessity to discover the attitude of the actor towards the actions of the character besides the impulses of the character, and Grotowski pursues impulses, which would lead to the emergence of special actions that take the actor out of everyday life and guide them as a vehicle in the way of being cultivated as a human being.
\end{abstract}

Keywords: Acting, action, Stanislavski, Brecht, Grotowski.

Academical disciplines/fields: Theory of acting, theatre theory.

* Bu makale, yazarın 2016 yılında Ankara Üniversitesi ‘Tiyatro Kuramları, Eleștiri ve Dramaturgi' doktora programı çerçevesinde savunduğu 'Canlı Bir Deneyim Olarak Oyuncunun Sanatı ve Geleneksel Performans Sanatlarında İcra' ismini taşıyan doktora tezinden üretilmiștir.

- Sorumlu Yazar: Sebnem Sözer Özdemir, Sahne Sanatları Bölümü, Sanat, Tasarım ve Mimarlık Fakültesi, Düzce Üniversitesi.

- $\quad$ Adres: Düzce Üniversitesi, Sanat, Tasarım ve Mimarlık Fakültesi, Konuralp, Çiftepınarlar Mah. Türbe Sok. No: 7/1, 81060, Düzce.

- $\quad$ e-posta: sebnemsozerozdemir@yahoo.com.tr

- ORCID: 0000-0001-5957-4306

- Cevrimiçi yayın tarihi: 14.12 .2021

- doi: $10.17484 /$ yedi.777131 


\section{Giriș}

Aksiyon, Batılı tiyatro kuramları içinde sıklıkla karşımıza çıkan ve 20. yüzyıldan itibaren özellikle oyunculuk bağlamı içinde tartışılan önemli bir kavramdır. Bu kavram hakkında çeșitli sanatçlar ve kuramcılar farklılaşan fikirler ileri sürse de, oyuncunun sanatının aksiyon(lar) oluşturmak/yaratmak olduğu konusunda bir fikir birliği olduğunu söylemek mümkündür. Bu makalede 20. yüzyılda yaşamış üç önemli Batılı tiyatro insanı olan Konstantin Stanislavski (1963-1938), Bertolt Brecht (1898-1956) ve Jerzy Grotowski'nin (1933-1999) geliştirdikleri oyunculuk anlayıșları üzerinde durulacak ve bu birbirinden farklı anlayışlar aksiyon kavramı çerçevesinde karşılaştırmalı olarak incelenecektir.

Aksiyon kavramı, tiyatro kuramı içinde ilk olarak, bir oyunda karakterlerin davranışları sonucunda ortaya çıkan sahne olayları dizisini belirtmek için kullanılmıştır. Fakat bu tanımıyla aksiyon çok önemli bir başka tiyatro kavramı olan 'olay örgüsü' ile ayrıştırılamaz bir haldedir. Zaman içinde bu iki kavram arasındaki ayrım netleşmeye başlamış ve aksiyon kavramının tanımında bir durumdan diğer duruma geçişi sağlayan dönüştürücü güçler fikri daha çok vurgulanır hale gelmiştir (Pavis and Shantz, 1999, s. 9-11). Bu tanımıyla aksiyon artık "dramatik durumların mantıksal ve zamansal dizileri"ni (Pavis and Shantz, 1999, s. 10) ifade etmeye başlamıştır. Bu daha sonra ortaya çıkan, geçiş ve süreklilikle ilişkilendirilen aksiyon tanımının izlerini gerek Stanislavski'nin gerekse Brecht'in tiyatro ve oyunculuk anlayışları içinde sürmek mümkündür.

Bununla birlikte 20. yüzyıl içinde kimi sanatçılar tarafından diğer tiyatro konvansiyonları ile birlikte aksiyon kavramının da eleştirisi yapılmaya başlanmıştır. Hatta Antonin Artaud (1896-1948) gibi sanatçılar bu kavramın içindeki dramatik temsil (mimesis) fikrini tamamen reddederek tıpkı bir ritüelde olduğu gibi kendinden başka bir şeyi temsil etmekle ilgilenmeyen, yoğun ve etkili, gerçek aksiyonların oluşturulmasının peșine düşmüştür (Pavis and Shantz, 1999, s. 13). Öte yandan İngilizce 'action' (aksiyon) ve 'actor' (oyuncu, aktör) terimlerinin 'to act' yükleminden türetildiği olgusu üzerinde durmak önemlidir.2 Güney Asya kökenli dramatik biçimlerin yanında dövüș ve meditasyon sanatları üzerine de çalıșan ve bu çalışmalardan yoğun esinler taşıyan kendi oyunculuk anlayıșını 'vücut bulmuş/bedenlenmiş aksiyon (embodied action)' kavramı ile ortaya koyan İngiliz tiyatro yönetmeni ve kuramcısı Phillip Zarrilli, İngilizcedeki 'act'in kökeninin Latince yapma/etme (doing) anlamına gelen 'actus' olduğunu ve 'actus'un da Latince yapmak/etmek (to do) anlamına gelen 'agere' yükleminden türetilmiş olduğunu belirtir. Bu bağlamda 'actor', 'doer' anlamına, Türkçe söylersek 'yapan/eden' anlamına gelmektedir (Zarrilli, 2013, s. 9). Grotowski'nin ortaya attığı tiyatro ve oyunculuk yaklaşımları bu aksiyon ve oyuncu tanımlamalarına oldukça yakın bir anlayış etrafında biçimlenmiştir.

Batılı aksiyon kavramı elbette tiyatro sanatı ve kuramı dışında da varlığını sürdürmektedir. Kültürel antropolog Victor Turner (1982), Ritüelden Tiyatroya (From Ritual to Theatre) adını taşıyan kitabında 'act' yükleminden türeyen 'acting' (yapma) teriminin kullanımındaki muğlaklık üzerinde durur. Acting ilginç bir biçimde hem gündelik yaşama ait etkinliklerle (iş), hem de gündelik-dışı sayılan sahne performansları (oyun) ve tapınak performanslarıyla (ritüel) ilişkilendirilmektedir:

Acting, tüm 'basit' Anglosakson sözcükler gibi, muğlaktır - gündelik yaşamın içinde bir şeyler yapma ya da sahne üstünde veya bir tapınakta performansta bulunma anlamlarına gelebilir. ...Bir bedenin ya da makinenin 'aksiyon'u gibi- bir çalışma ya da hareket etme biçimi olabilir; ya da oyunlarda performansta bulunma sanatı ya da mesleği olabilir. Dürüstlüğün özü- belki de 'kişisel hakikati' gerçekleştirmek için etik gerekçelerle kişinin benliğini bir aksiyon çizgisine adaması- olabilir, ya da rol yapmanın özü- kişi bir şeyi saklamak ya da gerçekleri gizlemek için 'bir parça oynadığı' zamanki gibi- olabilir. İlki Jerzy Grotowski’nin 'Yoksul Tiyatro'sunun idealidir; diğeri her gün 'ișteyken' gerçekleșir. ...Dolayısıyla acting hem iş hem oyun, hem ciddi hem oyunsudur. (Turner, 1982, s. 102)

Batı diline ait 'act' yükleminin bu çok anlamlı yapısının bu kültür içinde üretim yapan çeşitli tiyatrocuları farklı oyunculuk yaklaşımları getirmeye itmiş olduğunu söylemek mümkündür.

\footnotetext{
2 Batı kökenli bir terim olan aksiyonun Türkçe karşılığı olarak 'eylemek' yükleminden türetilmiş 'eylem' sözcüğünün kullanılmaktadır (Aksiyon, t.y.). Bununla birlikte 'to act' oynamak sözcüğü ile, 'actor' ise genellikle oyuncu sözcüğü ile karşılanmaktadır. Aynı zamanda Türkçede oyuncu için çok yaygın olmamakla birlikte aktör kelimesinin kullanıldığı da görülür (Act, t.y.a; Actor, t.y.b).
} 


\section{Stanislavski ve Fiziksel Aksiyon}

Oyuncunun yapma/etmesine vurgu yapan kuramcılar arasında kronolojik olarak ilk sırayı oyunculuk üzerine pratiğe dayalı ve bir yöntem oluşturmaya yönelik ilk geniş ölçekli araştırmayı başlatmış olan Rus oyuncu ve yönetmen Konstantin Stanislavski alır. Stanislavski oyunculuk kökenli bir tiyatrocuydu ve oyunculuk üzerine araştırmalarını hayatının son günlerine dek sürdürdü. Bu araştırmaların içinde aksiyon kavramı da önemli bir yer tutuyordu. Her ne kadar bugün bütünlüklü olduğu varsayılan bir Stanislavski Yöntemi'nden söz ediliyor olsa da, kolay tatmin olmayan bir sanatçı olan Stanislavski gerçekte sanat hayatının farklı dönemlerinde farklı teknik araçlar üzerine çalışmış, bu araçların bir kısmını zaman içinde geliştirirken bazılarını eleştirip terk etmiştir. Gene de onun çalışmalarını bütünlüklü kılan temel öğe hiç bıkmaksızın üzerine çalıștığı oyunculuk sorunlarıdır. Amerikalı tiyatrocu ve Stanislavski uzmanı Sonia Moore, "Stanislavski'nin tüm hayatı boyunca süren araştırma konusu insan aksiyonudur" (2005, s. 161) diye belirtir. Ona göre bu araştırmadaki temel amaç oyuncunun yaratıcı esin anlarının bilinç aracılığıyla kontrol edilebilmesini sağlayacak araçları bulmaktır (Moore, 2005, s. 160).

Stanislavski çalışmalarında iki tür aksiyonun adını anar: a) 'iç aksiyon', 'içsel aksiyon' ya da 'psikolojik aksiyon', ve b) 'dış aksiyon', 'dışsal aksiyon' ya da 'fiziksel aksiyon'. Her ne kadar bu ayrım ilk bakıșta Kartezyen bir ruh-beden ikiliğini anıştırsa da Stanislavski bu tür bir ayrıștırmanın karşısındadır; çünkü her zaman en büyük derdi oyuncunun dışsal davranışları ile içsel yaşantısının birliğini sağlamak olmuştur. Oyuncu ancak o zaman onun hayatı boyunca talep ettiği ve 'doğallık' olarak adlandırdığı yapmacıklıktan uzak inandırıcılığa ya da hakikiliğe ulaşacaktır. Bu sebeple iç aksiyon ve dış aksiyonu Stanislavski'nin kabul ettiği haliyle 'oyuncu aksiyonu'nun sadece kuramsal boyutta ayrışmış olan iki yönü olarak kabul etmek daha doğrudur. Bununla birlikte oyuncunun çalışması içinde hangisinin zamansal önceliğe sahip olduğu konusundaki yaklaşımları açısından Stanislavski'nin oyunculuk araştırmaları iki temel döneme ayrılabilir. 1930'lara kadar uzanan ilk döneminde iç aksiyona daha çok vurgu yaptığı görülse de, aslında her iki dönemindeki birincil düşmanı sahne üzerinde inandırıcılıktan uzak bir takım hareketler yapan ve/veya klişe trükler ile seyircileri etkilemeye çalışan oyuncu tipidir. Ona göre oyuncunun sahne üzerindeki her hareketi içten gelen bir nedenle bağlantılı olmalıdır. Bu iç-dış birliğini sağlamak üzere araştırmalarının ilk döneminde oyuncudan oynayacağı rolün içinde bulunduğu durumu ve duygularını en iyi şekilde kavrayabilmesi için masa başında metne dayalı uzun psikolojik karakter analizleri yapmasını talep eder. Oyuncu rol kişisiyle empati kurmalı, onunla ‘özdeşleşme'li, hatta ona dönüşmelidir. Bu dönemde oyuncunun rolüne yaklaşırken kendi hayatından ve anılarından yola çıkmasını öneren 'duygusal bellek' (ya da 'coşkusal bellek') ve oyuncular arasında hakiki duygu-düşünce alışverişi sağlamayı hedefleyen 'karşılıklı ışın gönderme' (ya da 'coşkusal ışımalar') gibi araçlar ortaya atar. Bu anlayışa göre rolün içsel yaşamının keşfi ve hakikiliği, oyuncunun sahne üzerinde rolün dıșsal davranışlarını oluşturmasına yardım edecektir. 1930’lara gelindiğinde Stanislavski o güne kadar üzerinde çalıștığı oyunculuk yönteminde bir şeylerin yolunda gitmediğini fark eder. Oyuncular masa başında metni yoğun bir şekilde inceleyip oyunun ve karakterlerin analizi için uzun saatler harcadığında büyük bir kafa karışıklığı içinde sahne üzerinde kendilerini engellemektedirler. Öte yandan güvenilmez ve değişken olan duygulardan yola çıkıldığında ise sabitlenemeyen, dolayısıyla her oyunda tekrarlanamayan ve hatta oyuncunun ruhsal sağlığına zarar verebilecek sonuçlar ortaya çıkabilmektedir. Bu sorunlar Stanislavski'nin hayatının son beş yılında 'Fiziksel Aksiyon Yöntemi'ni ya da tam ismiyle söylemek gerekirse 'Fiziksel Aksiyon Aracılığıyla Analiz Yöntemi'ni geliştirmesine yol açacaktır. Araştırmasını halen sürdürürken hayatını kaybetmesine ve ufak tefek notlar dışında bu konuda yazılı bir eser bırakamamasına rağmen 'Fiziksel Aksiyon Yöntemi'nin Stanislavski'nin tiyatroya yaptığı en önemli katkısı olduğu dile getirilir. Bizzat kendisi de bu yöntemin hayatı boyunca aradığı şey olduğunu söylemiştir. Bu yöntemin getirdiği en önemli yenilik oyuncunun rolünü araştırmaya (ya da analiz etmeye) güvenilir bir yerden, kolayca ulaşabileceği bir yerden başlaması önerisidir; bu yer 'oyuncunun kendi bedeni'dir. Artık oyuncu masa başı analiz süreçlerine ve duygusal arayışlara hiç sokulmadan hemen 'fiziksel aksiyon'un içine atılmaktadır. Ondan talep edilen, bizzat kendi olarak karakterin içinde bulunduğu durumdan doğan 'fiziksel aksiyon çizgisi' üzerine çalışması ve kendine bu durumda kendisi olsa ne yapacağı, ne isteyeceği sorularını sormasıdır. Bu yönteme 'sihirli eğer' adı verilmektedir. Oyuncu rolün içinde bulunduğu 'verili durumlar'la bağlantılı olarak kendine nerede olduğunu, etrafında kimler ve neler olduğunu ve ne yaptığını sorar. Örneğin eğer oyun kişisi bir sahneye evin kapısını açarak başlıyorsa, oyuncu da işe bu aksiyon üstüne çalışarak başlamalıdır. Fakat bu hiçbir şekilde sadece sahne üzerindeki hareketleri gerçekleştirmeye ve sabitlemeye yönelik bir araştırma değildir. Çünkü fiziksel aksiyon hareketten öte bir şeydir. Bir kapıyı açmak sadece bir hareketken, bir kapıyı ardında tehlikeli birinin olduğu bilgisiyle açmak 'fiziksel aksiyon'dur. Fiziksel aksiyon söz konusu olduğunda işin içine rol kişisinin o sahneye ait verili durumu girmiştir ve bunun sahne üzerinde ne gibi hareketlere dönüşeceği oyuncunun söz konusu duruma vereceği tepkilere bağlıdır. Bu doğrultuda oyuncu verili 
durumları karakterin fiziksel aksiyonlarını gerçekleştirerek analiz etmeye koyulur. Ondan beklenen duygularına değil, rol kişisinin içinde bulunduğu fiziksel aksiyonlara odaklanması ve oyunun fiziksel aksiyon çizgisini oluşturup bunu sahne üzerinde tam anlamıyla gerçekleştirmesidir. Bu doğru şekilde başarıldığında duygular da kendiliğinden ve doğru şekilde ortaya çıkacak, oyuncunun dışsal davranışları ile içsel yaşamı arasında bir birlik kurulacaktır. Burada rolün analizinin dıştan içe doğru yönelmiş olduğu söylenebilir, ama halen temel amaç oyuncunun içsel yaşamı ile dıșsal davranışlarının bütünlüğünün sağlanmasıdır (Benedetti, 2004; Coger, 2005; Moore, 2005; Richards, 2005; Tanyel ve Esen, 1996; Yaralı ve Karaboğa, 2005). Amerikalı tiyatro uzmanı Leslie Irene Coger 'Stanislavski Fikir Değiștiriyor' isimli makalesinde bu yeni yöntemin doğuşunu şöyle anlatır:

Fiziksel aksiyonların kullanımı, rolün analiz ve alıștırmalar yoluyla yaratıldığı ve daha sonra oyunun koşullarına uyarlandığı bu Sistem'de bir dönüm noktası olarak görülebilir. Ama Stanislavski asla çalıșmanın bir bölümünü vurgulamak pahasına diğerini harcamaya razı olmaz. ..."psikolojik aksiyon ve fiziksel aksiyon aynı sürecin parçasıdır." Olan şey şudur ki Stanislavski fiziksel aksiyonları, bir oyuncunun dışsal aksiyonu gerçekleștirmesine izin veren içsel yaşama yönelik bir ihtiyaç yaratmak için kullanıyordu. (2005, s. 167)

Stanislavski nihayet bilinç yoluyla kolaylıkla kontrol edebileceği ve sayesinde bilinçsiz olanın uyarılabileceği bir yöntemi keşfetmiştir. Duygular kontrol edilemese de duyguların ortaya çımasına yol açan fiziksel aksiyonlar kontrol edilebilmektedir. Moore psikolojik olarak görülen ilk dönemi ile fiziksel aksiyonun vurgulandığı ikinci dönemi arasında Stanislavski'nin amaçları ve inançları açısından bir süreklilik olduğunu belirtir:

Stanislavski insan davranışının psiko-fiziksel bir süreç olduğunu keşfetmiş̦ti... Örneğin, fiziksel bir eylem olarak bir bardağı yukarı kaldırırsam, bunu bazı içsel ya da psikolojik nedenlerden dolayı yaparım: Susamış olabilirim ya da içinde ne olduğunu görmek isteyebilirim. ...

$\cdots$

İnsanda psikolojik olan ve fiziksel olan bölünmez bir birlik içinde olduğundan, fiziksel bir aksiyonun gerçeğe sadık bir biçimde icra edilmesi oyuncunun hakiki coşkularını devreye sokar. (2005, s. 159-160)

Gerçekte Stanislavski için 'aksiyon'un tanımı her döneminde aynı kalmıştır; ona göre aksiyon içsel yaşam ile dışsal davranışların bütünlügüdür. Bir başka Amerikalı tiyatrocu ve Stanislavski uzmanı Sharon Marie Carnicke (2003) özellikle Amerika Birleşik Devletleri'nde yaygın olan Stanislavski'nin psikolojik bir oyunculuk geliştirdiğine dair yanlış anlamanın temel kaynağı olarak Elizabeth Reynolds Hapgood'un yaptığı erken dönem İngilizce çevirileri gösterir. Stanislavski Bir Aktör Hazırlanıyor adını verdiği kitabının Rusça orijinalinde Rusça ve İngilizce drama kavramının kökeni olan Yunanca dran sözcüğünü anmakta ve bu sözcüğün 'yapmak/etmek' anlamına geldiğini özellikle belirtmektedir, fakat bu bölüm nedense Hapgood'un çevirisinde atılmıştır (Carnicke, 2003, s. 88). Bununla birlikte Stanislavski baştan beri kendi oyunculuk anlayışını ve aksiyon tanımını ortaya koyma yolunda Rusçada oyunculuk bağlamında kullanılagelen ve 'oyun' ve '-mış gibi yapma' vurgusunu taşıyan igrat yüklemini net bir şekilde reddederek, onun yerine 'yapmak/etmek' anlamına gelen deisvovat yüklemini ve aksiyon olarak çevrilebilecek deistvie sözcügünü kullanmayı tercih etmiştir. Her iki yüklemin İngilizce'ye Hapgood tarafından to act olarak çevrilmesi Stanislavski'nin bilinçli olarak yaptığı bu ayrımı gizlemiştir. Deisvovat fiilinin önemli bir özelliği aynı zamanda bir amaçla yapmak, harekete geçmek (to take action) vurgusunu taşımasıdır (Carnicke, 2003, s. 88-90). Stanislavski oyuncuyu açıkça 'yapan/eden', aksiyonun içindeki kişi olarak tanımlıyordu. Stanislavski'nin aksiyon yerine kullandı̆̆ deistvie kelimesinin İngilizceye Hapgood tarafından kimi zaman inner intensity, Türkçe söylersek 'içsel yoğunluk/gerilim' olarak da çevrildiği görülmektedir (Carnicke, 2003, s. 90) Bu ince ayrıntı Stanislavski sisteminde duyguların çok önemli olduğuna dair bir yanlış anlaşılma yaratmış olsa da, aslında Stanislavski’nin aksiyon tanımının özünü belirtir niteliktedir. Stanislavski için oyuncunun aksiyonu hiçbir zaman sadece hareket etmek değildir ve olmamalıdır. Aksiyon ya da deistvie içinde bir istek, bir amaç, bir itki taşıyan bir harekettir (Carnicke, 2003, s. 90-92); içsel bir gerilimden doğar. Stanislavski'nin 'doğallık' tanımı işte tam da budur, çünkü gerçek hayatta her zaman bir itki ile harekete geçeriz. İnsan sadece su içmek için su içmez, susadığı için ya da sıkılıp ne yapacağını bilmediği için ya da başka bir nedenle su içer. Stanislavski oyuncusundan sahnede gerçek hayattaki gibi bir nedenle, bir itkiyle, bir istekle hareket etmesini/harekete geçmesini ister, onu sahtelikten doğallığa ulaştıracak olan giz buradadır. Bu aksiyon tanımının içine söz söylemek de dâhildir; oyuncu tıpkı gerçek hayattaki gibi bir nedeni olmayan hiçbir söz söylememelidir. Ne yazık ki Stanislavski'deki doğallık vurgusu sıklıkla 
oyuncuların doğalmış, çok rahatmış gibi görünen, ama gerçekte amaçsız olan hareketler sergileme yoluna gitmesine yol açar. Oyuncular içlerinde herhangi bir itki hissetmeden 'doğal-mış gibi' yaparlar. Bunun çaresi olarak ortaya çıkan Fiziksel Aksiyon Yöntemi'nde ise amaç "aksiyona itki sağlayan şeyi keșfetmek"tir (Coger, 2005, s. 167-168). Bu bulunduğunda ve oyunun bütünlüğü içinde doğru şekilde ilişkilendirildiğinde iç ile dış, duygular, düşünceler, niyetler ve itkiler ile eylemler, jestler ve sözler bir bütün haline gelecektir. Araştırılan süreç karakterin psiko-fizyolojik sürecidir. Oynadığı karakterin fiziksel aksiyonlarının küçük ayrıntıları üzerinde çalışan oyuncu, bir dramatik durumdan diğerine geçişe neden olan güçleri keşfederek bir 'fiziksel aksiyon çizgisi' ya da 'fiziksel aksiyon skoru' oluşturur ve Stanislavski'nin 'üstün-amaç' ya da 'üstün-yönelim' diye adlandırdığı karakterin oyundaki olay örgüsünün bütününe yayılan temel isteğini keşfetmeye başlar (Tanyel ve Esen, 1996). Sonuç olarak ortaya çıkan kişi, ne metindeki karakter ne de oyuncunun kendisidir; ikisinin arasında bir noktada yer alan üçüncü bir varlıktır (Benedetti, 2004, s. 95). Stanislavskiyen yönteme özgü bu süreç temel olarak 'karakter yaratmak' terimi ile anılır. Bu noktada bu sürecin ne sadece psikolojik ne de sadece fiziksel olduğunu ayırt etmek önemlidir; Zarrilli, Stanisklavski'nin kendisinin psikolojikten ziyade 'psiko-fiziksel' terimini kullanmayı tercih ettiğini özellikle belirtir (2013, s. 7).

'Oyun' vurgusu taşıyan igrat yüklemini reddeden Stanislavski'nin de Zarrilli gibi oyuncuyu bir 'yapan/eden' olarak tanımladığı görülmektedir. Ona göre oyuncu her ne yapıyorsa onu gerçekten yapmalıdır. Peki ama oyuncu canlandırdığı rol kişisi ne yapıyor olursa olsun, aynı anda 'oynamak' eylemini de gerçekleștirmez mi? Oynamak eyleminin kendisi de bir aksiyon değil midir; bu eylemi de bir nedenle, bir amaçla, bir itkiyle gerçekleştirmez miyiz? Bu sorular bizi kendi tiyatro ve oyunculuk anlayışını Stanislavski'nin aksine oyuna ve oynamak eylemine pejoratif olarak yaklaşmadan kuran Alman yönetmen Bertolt Brecht'e doğru yönlendirmektedir.

\section{Brecht ve Oyuncunun Ek Aksiyonu}

Stanislavski'nin oyunculuk yöntemine en önemli eleștirileri getirenlerden biri Brecht olmuștur. Eleștirisi daha çok Stanislavski'nin ilk dönemine ilișkindir. Oyuncunun oynadığı karakterle özdeșleșmesine dayanan psikoloji temelli bir oyunculuğa şiddetle karşı çıkan Brecht, bu yaklaşımın seyircinin de karakterle özdeşleşmesine ve oyunun olay örgüsünü kendi gözleriyle değil karakterin gözleriyle görmesine yol açtı̆̆ından şikâyet eder. Oyunu kendi gözleriyle göremeyen seyirci, sahnede olan biteni sorgulamak yerine hipnotize olmuş bir biçimde sanki bütün izledikleri hayatın doğal, kaçınılmaz akışıymış gibi onları kabullenmektedir. Brecht kendi önerdiği tiyatro açısından son derece olumsuz olarak gördüğü bu sonuçtan kaçınmak için 'özdeşleşme'nin karşısına 'yadırgama/yadırgatma' aracını koyar. Bu araç sayesinde oyuncu oynadığı karakterle arasına eleștirel bir mesafe koyacak, bu sayede seyircinin de izlediği oyunla arasına eleștirel bir mesafe koymasına firsat verecektir. Böylece seyirci hipnotize edilmekten kurtulacak, her zaman bir oyun izlediğinin farkında olacaktır. Gene de bu Brecht'in temel olarak oyuncunun (ve onun sayesinde seyircinin) karakterle özdeşleşmesine ya da empati kurmasına dayanan Stanislavski yöntemini bütünüyle kenara ittiği anlamına gelmez. Brecht 'tamamlanmamış özdeşleşme'den bahseder. Oyuncu provalar sırasında ilk aşamada oynadığı karaktere empati duymalı ve onun içinde bulunduğu durumla özdeşleşmeli, ama sonra karakteri dışarıdan, uzaktan, eleştirel bir bakış açısıyla görmeyi de başarmalıdır. Sahne üzerinde ise bu iki çelişen durum oyuncu tarafından bir arada yaşanmalıdır. Brecht ne salt özdeşleşmeyi ne de salt eleştiriyi kabul eder (Bentley, 2005; Brecht, 2005a, 2005b; Mumford, 2005). Onun için önemli olan özdeşleşme ve yadırgama, karakter ve oyuncu arasındaki diyalektik ilişkidir. Tiyatro İçin Küçük Organon'a yazdığı ekte Brecht bu görüşünü şu şekilde açıklar:

Oynamak (sergilemek) ve yaşamak (özdeșleşmek) arasındaki çelişki deneyimsiz kafalarca, sanki oyuncunun çabalarıyla bunlardan yalnızca biri ortaya çıkabilirmiş...gibi kavranır. Gerçekte ise birbirine düşman, ama oyuncunun çalışmasında birleşen iki olayın varlığı söz konusudur (yani oyun, biraz birini, biraz da ötekini içeriyor değildir). Oyuncu gerçek etkilerinin kaynağını iki karşıtllğ̆ın savaşında, geriliminde ve derinliğinde bulur. (2005b, s. 73)

Peki oyuncu bu zor görevi nasıl gerçekleştirecektir? Brecht bu görevi yerine getirmek için oyuncunun karakterin aksiyonuna ek olacak bir aksiyon daha yaratmasını talep eder. Bu 'ek aksiyon', oyuncunun, karakterin aksiyonuna verdiği tepkiden doğacak ve sahne üzerinde karakterin aksiyonuyla eş zamanlı olarak gerçekleştirilecektir. Tümden özdeşleşmeye engel olacak olan 'oyuncunun ek aksiyonu'nun varlığı, seyircinin karakterin aksiyonu üzerine eleştirel bir bakış açısıyla düşünmesine olanak verecektir (Brecht, 2005a). Bir bakıma bu tip oyunculukta oyuncunun sanatının içsel işleyiş̧inin saklanmak yerine görünür kılındığı söylenebilir. Seyirci aynı anda hem karakterin aksiyonunu, hem de bu aksiyonla bir uğraş içinde 
olan, onunla hem özdeşleşen hem de aynı anda özdeşleşmekten geri duran oyuncunun aksiyonunu izlemektedir.

Brecht'in yönteminde Stanislavski'nin aksine artık oyuncu karakterin arkasına saklanmamaktadır, oyuncu görünür olmuştur. Fakat burada bir konuya dikkat etmek önemlidir; görünür kılınan oyuncunun kişisel hayatı değil, oyunun rejisi ile bağlantılı olarak oyuncunun karakter hakkındaki eleștirel bakışıdır. Görünen bir insan değil, bir 'oyuncu tavrı'dır. Aksiyon tartışması açısından baktığımızda, Brecht'in ek aksiyon olarak tanımladığı bu oyuncu tavrının bir 'oynama aksiyonu' olduğunu söylemek mümkündür. Amerikalı performans araştırmaları kuramcısı ve yönetmen Richard Schechner 'oyun oynama'yı aynı anda hem bir 'akış' (flow), hem de 'kendi üstüne düşünme' (reflexivity) olarak tanımlar; oynayanlar bir yandan bir oyun oynadıklarının farkındayken, bir yandan da oyunu oynamak için kendilerini oyuna kaptırmak durumundadırlar (2013, s. 91). Stanislavski yönteminde gizlenen oyuncunun oynama eylemi, Brecht'in tiyatrosunda açık edilmektedir. Bu farka rağmen Brecht'in Stanislavski'nin ikinci dönemi hakkında daha olumlu düşüncelere sahip olduğunu görürüz. Hatta Brecht (2005a) Stanislavski'nin tiyatroya yaptığı en büyük katkının geliştirdiği 'Fiziksel Aksiyonlar Yöntemi' olduğunu söyler. Ona göre fiziksel aksiyon çizgisinin keşfedilmesi aracılığıyla karakterin ve oyunun 'üstün-amacı'nın ya da 'üstün-isteği'nin araştırılması 'Brechtyen' bir yöntemdir. Çünkü burada vurgu Brecht'in istediği şekilde oyunun dramatik aksiyon dizisinin, yani bir dramatik durumdan başkasına geçişe neden olan güçlerin analiz edilmesine yöneliktir. Karakterin fiziksel eylemlerine ait itkilerinin araştırılması ve analiz edilmesi, en nihayetinde oyunun üstün amacının analiz edilmesini sağlayacaktır. $\mathrm{Bu}$ analiz oyuncunun ek aksiyonunu, yani karakterin aksiyonlarına ve oyunun aksiyon çizgisine vereceği tepkisini oluşturmasına da yardım edecektir.

Eğer 'oynama aksiyonu' diye bir şeyden söz edilebiliyorsa, o halde bu aksiyonun itkisinden, daha doğrusu 'oynamanın itkisi'nden de söz etmek gerekir. Brecht'in yaklaşımında oyuncunun bir karakteri oynamak için bir itkiye ihtiyacı olacaktır. Örneğin oyuncu karakterin aksiyonlarını haklı ya da haksız mı göstermeyi istemektedir? Bir yandan uzak dururken aynı anda özdeşleşmekte olduğu karakterin aksiyonlarını sürdürmeyi mi, yoksa durdurmayı mı arzulamaktadır? Tüm bu itkiler karakterin itkilerinin üstüne eklenerek görünür kılınır. Bu tiyatro yaklaşımında karakterin aksiyonlarını doğuran itkiler kadar oyuncunun oynama eylemini doğuran itkiler de bir o kadar önemlidir ve amaç bu ikisi arasındaki diyalektik ilişkinin ortaya çıkarılmasıdır. Peki ya oynama eyleminin itkilerini karakterin itkileriyle eşit konuma getirmek yerine onun da önüne koyar ve tiyatronun en önemli etmeni kllarsak ne olur? Oyuncunun aksiyonunun gizlenmemesi ve hatta en önemli unsur kılınmasını öneren önemli isimlerden biri Polonyalı yönetmen Jerzy Grotowski’dir.

\section{Grotowski ve Literal Aksiyon}

Grotowski tıpkı Stanislavski gibi sanat yaşamı boyunca farklı aşamalardan geçmiş ve farklı niteliklerde çalışmalarda bulunmuştur. Bu çalışmalarını sırasıyla 'Gösterim Tiyatrosu' (ya da 'Sunum Olarak Sanat'), 'Para-Tiyatro', 'Kaynaklar Tiyatrosu' ve son olarak 'Araç Olarak Sanat' dönemleri olarak adlandırır (Grotowski, 2005). Bu dönemlerin her biri öncekilerin içinden doğan, daha önceki araştırmalarda ortaya çıkan sorular yönünde gelişen yeni araştırmalar olarak görülmelidir. Aslında Grotowski de Stanislavski gibi sürekli olarak bazı temel soruların peşinden gitmiş, insanın nasıl bütün olacağı ve gerek dünyayla gerek başkalarıyla nasıl gerçek bir iletişim kuracağı gibi meselelerle ilgilenmiştir. Ona göre Artaud insanın nasıl kendisi olacağı şeklinde çok önemli bir soru sormuş, ama insanın nasıl bütün olacağı sorusunu sormamıştır (Grotowski, 2002, s. 96).

Öte yandan her ne kadar kendini ondan ayırsa da, Grotowski yöntemsel olarak Stanislavski'nin takipçisi olduğunu belirtir. Stanislavski'nin çalışmalarının en değerli parçasının üzerine yeterince çalışma fırsatı bulamadığı 'Fiziksel Aksiyonlar Yöntemi' olduğunu ve kendi çalışmasının bu yöntemi alıp ileri götürdüğünü söyler. Gerek 'Gösterim Tiyatrosu' döneminde, gerekse 'Araç Olarak Sanat' döneminde fiziksel aksiyon çalışması Grotowski’nin araştırmalarının öncelikli bir parçası olmuştur (Richards, 2005). Grotowski’nin aksiyon tanımı Stanislavski'ninkine hem benzerdir, hem de ondan farklılaşır. Grotowski de aksiyonu Stanislavski gibi öncelikle itkilerden doğan bir şey olarak tanımlar; fakat onun hedefi oynanacak karakterin aksiyonlarını araştırmak değil, oyuncuyu gündelik olmayan bir bütünlüğe doğru taşıyacak özel bir aksiyonu yaratmak için ihtiyaç duyulan itkileri ortaya çıkarmaktır. Grotowski'nin son döneminde onun öğrencisi olmuş ve Grotowski Çalışma Merkezi'ni devralmış olan Thomas Richards bu farkı şöyle açıklar:

Grotowski, çalışmasında organiklik kavramını yeniden tanımlar. Stanislavski için 'organiklik', yapı ve kompozisyonun da yardımıyla sahnede beliren ve sanata dönüşen 'normal' yaşamın doğal ilkeleri anlamına gelir. Grotowski'de ise 
organiklik, bir itkiler akım gücü gibi bir șeyi, bedenin 'içinden' gelip kesin bir eylemin gerçekleştirilmesine giden neredeyse biyolojik bir akımı belirler. (2005, s. 132)

Grotowski'nin aradığg, "kısıtlamalardan arınmış bir bedende günlük yaşamla ilgili olmayan bir bütünlüğe giden organik itkiler"dir (Richards, 2005, s. 135). Yapılması gereken ise bu itkilerin rehberliğinde kesin ve ince bir şekilde işlenmiş, yinelenebilen bir yapının oluşturulmasıdır. 'Araç Olarak Sanat' döneminde Grotowski bu yapıya büyük harfle 'Aksiyon' ismini vermiștir (2005, s. 164, 176). Aslında Aksiyon'un öncüsü, Grotowski'nin ilk dönemi olan 'Gösterim Tiyatrosu' döneminde ortaya attığı 'bütünsel edim' kavramıdır. Yoksul Tiyatroya Doğru kitabında Grotowski bütünsel edimi oyuncunun sanatının düğüm noktası olarak gördüğünü belirtmiş ve bu edimi oyuncunun "ne yaparsa yapsın bütün varlığıyla yapması" (2002, s. 95) olarak tanımlamıştır. Her ne kadar bu tanım Grotowski'nin daha sonraları kullanmaktan kaçındığı 'mistik' tonları taşısa da, oyuncunun beden-zihin bütünlüğüne yaptığı vurgu açısından önemlidir. Grotowski’ye göre bütünsel edim eğer gerçekleştirilebilirse, oyuncunun tinsel ve fiziksel varlığının birbirinden ayrılmaz hale geldiği ve organizmasının bütünü aracılığıyla özel türde bir 'ruh hareketi'ni resmedecek güce ulaştığı bir varlık durumudur (Grotowski, 2002, s. 96). Bununla birlikte Polonyalı sanatçı bütünsel edimin aynı zamanda bir 'içtenlik edimi' olduğunu belirtir. Bu edim sırasında oyuncu kendini bütünüyle gerçekleştirdiği aksiyona vererek seyircilerin önüne toplumsal maskelerden sıyrılmış salt insan olarak çıkar (Grotowski, 2002, s. 97-98).

Her ne kadar bütünsel edim kavramı Grotowski'nin çalıșmalarını tiyatronun konvansiyonel sınırlarının ötesine, insan yaşamına dair daha geniş bir alana doğru çekmeye başlasa da, Polonyalı yönetmen söz konusu dönemde halen tiyatronun içinde hareket etmektedir. Oyuncu bütünsel edimi gerçekleştirirken seyirci bunu bir olay örgüsü ve karakterin aksiyonları arkasından izlemektedir (Grotowski, 2005). 'Para-Tiyatro' döneminden itibaren ise Grotowski'nin gösterim olarak tiyatro fikrinden uzaklaştığını görürüz. Katılımcı tiyatro fikrinin baskın olduğu bu dönemde seyirci-oyuncu ayrımı, hatta seyirci ve oyuncunun kendisi ortadan kalkmıştır; bunun yerine çeşitli eylemleri birlikte gerçekleştirmek üzere buluşan insanlar vardır. 'Para-Tiyatro' ve 'Kaynaklar Tiyatrosu' dönemlerinde Grotowski'yle beraber çalışmış olan Polonyalı antropolog Leszek Kolankiewicz o dönemde Grotowski'nin artık konvansiyonel anlamda tiyatro oyunları yönetmeye son vererek 'Kutsal Gün' olarak adlandırdığı, aksiyon niteliği taşıyan ve insanları özel koşullar içinde bir araya getiren etkinlikler yönetmeye başladığını belirtir: “Grotowski'nin o dönem yaptığı etkinlikler insanın kendi varoluşunu bütünlüklü olarak hissetmesini sağlayan birer happening, birer etkinlikti. İnsan ile aksiyon arasında bir sınır yoktur; insanın kendisi saf aksiyondur zaten” (2010, s. 90).

Grotowski'ye göre para-teatral sözcügünü kullanmaya başlamak bizi çok önemli iki soruyla karşı karşıya bırakmaktadır: "Herşeyden önce, oynamak/taklit etmek ve olmak arasındaki fark nedir? Ve ikinci olarak, gerçek bir toplanma nedir?” (1994d, s. 198). Bu sorular ve 'Para-Tiyatro' dönemindeki araștırmalar Grotowski'yi yavaş yavaş Polonya'dan ani ayrılışıly beraber yarım kalacak olan 'Kaynaklar Tiyatrosu' dönemine taşır. Grotowski dünyanın çeşitli yerlerinden ve geleneklerinden gelen insanları Polonya'nın kırsalında bir araya toplar. Farklı Avrupa geleneklerinden, Asya geleneklerinden (Hint, Japon, İslam), Afrika geleneklerinden, Kuzey Amerika Kızılderililerinin geleneklerinden, vb. oluşan çok kültürlü bir grup kurar. Bu çalışma bağlamında aranan șey, bu farklı kültürlere ait ritüel ve sanatsal tekniklerin bir sentezi değil, somut, insan bedenine ait olan, insanın kendisi üzerine çalışmasını olanaklı kılan kültür-ötesi ya da kültüröncesi aksiyonlardır. Çalışmaya katılanlar örneğin yalın bir yürüyüşü ararlar; fakat bu yürüyüş yapanın algısını değiştirecek, onu gündelik dışı bir deneyime doğru götürecek, insanın doğayla bütünlüğünü hissetmesini sağlayacak bir yürüyüș olmalıdır (Grotowski, 1994b; Grotowski, 1994c). Bütün bu çalışmalar süresince 'Para-Tiyatro' döneminde sorulan iki temel soru ve saf aksiyon tartışması halen geçerliliğini korumaktadır. Grotowski (1994a) 1978'de New York'ta yaptığı 'Aksiyon Literal'dir' başlıklı konuşmasında her ne kadar tiyatroda genellikle dekor ve sahne donanımı ile kendinden bașka bir mekânı temsil etmek üzere tanımlanmıș bir alan ile ilgilensek de bu alanın aynı zamanda çok iyi bildiğimiz üzere bir sahne olduğu ve üzerinde geçen olayların sahnede yer aldığını hatırlatır. Böylelikle dinleyicileri mekânın başka bir mekânı temsil etmediği, bir olay her nerede gerçekleşiyorsa bizzat orada gerçekleştiği bir durum üzerine düşünmeye davet eder. Böyle bir durumda eğer bir güneş varsa bu gerçek bir güneş, bir ağaç varsa bu gerçek ağaç olacak, her şey her ne ise o olacaktır. Grotowski'ye göre aynı durum insan için de geçerlidir. Ağacın altında duran bir kiși varsa bu kiși kendisidir ve bașka biriymiș gibi davranmasına gerek yoktur. Fakat böyle bir durum tiyatro söz konusu olduğunda önemli bir sorunun ortaya çıkmasına yol açar, çünkü tiyatro sanatı konvansiyonel olarak oyuncu/karakter ikiliği üzerine kurulmuştur:

Sahne üstünde, bir tiyatroda, genelde bir rol oynarız. Eğer, Kral Lear'ı oynayacaksam, kendimle Kral Lear arasındaki fark benim başka birini oynadığımın farkında olmama yetecek kadar büyüktür. Ama eğer o ağacın 
altındaki kendim olacaksam, dehșet verici bir soru doğar: Hangi kendim? Arkadaşlarımın bildiği mi? Düșmanlarımın bildiği mi? Başkalarının bilmesini istemediğim kendim mi? Hayalini kurduğum mu? Hoşlanmadığım mı?

$\ldots$

Belki de -Bir kimse nasıl kendisi olur?- sorusunu hiçbir biçimde sözcüklerle yanıtlayamayız. Ama hiç kuşku yok ki eğer kendimizi unutursak, yanıt aksiyon içinde bulunabilir. (1994a, s. 172)

Böyle bir çalıșmada artık temsile dair herhangi bir şeyden söz etmek mümkün değildir. Var olan șeyler başka şeyleri, var olan mekân başka bir mekânı, oyuncular karakterleri temsil etmemektedir. Her şey her neyse odur, aksiyon literaldir ve kendisinden başka bir şeyi temsil etmemektedir. Grotowski çalışmalarına katılanlardan beklentisini şöyle açıklar: "[B]urada ve şimdi olmak, neredeyse orada olmak, ne yaparsa onu yapmak, kimle karşılaşıyorsa onla karşılaşmak” (1994a, s. 174). Bunu başarmanın ödülüyse kendini gerçekleştirdiği aksiyonun içinde unutup, 'ben' imgesinden bütünüyle kurtularak özel bir 'oluş' hâline geçmektir.

Teatral bir dile geri dönersek, Grotowski'nin 'Para-Tiyatro' ve 'Kaynaklar Tiyatrosu' dönemlerinde, sürdürdüğü 'saf aksiyon' ya da 'literal aksiyon' arayışı içinde artık karakterin aksiyonunu bütünüyle geride bıraktığını söylemek mümkündür. Stanislavski'de ve Brecht'te var olan karakterin aksiyonu/oyuncunun aksiyonu ikiliği burada bütünüyle ortadan kalkmıştır. Geriye sadece oyuncunun ya da artık bütünüyle 'yapan/eden' haline gelmiş olan insanın aksiyonu kalmış gibidir. Fakat Grotowski bizi şaşırtır; bu iki dönemdeki araştırmaların izlerinin halen devam ettiği 'Araç Olarak Sanat' döneminde 'Gösterim Tiyatrosu' döneminde üzerinde çalıştı̆̆ 'Fiziksel Eylemler Yöntemi' araştırmasına geri döner. 'Araç Olarak Sanat' dönemindeki çalışmalarda belirleyici olan, katılanların aynı anda hem fiziksel eylemler hem de (özellikle Karayipler'e ait) bazı eski geleneksel şarkılar üzerinde çalışmalarıdır. Grotowski 'Araç olarak Sanat' terimiyle artık çağdaş dünyada unutulmuş bulunan bir şeyden bahsettiğini belirtir:

Eylem'in öğeleri, dolaysız etkileri üzerinden onu yapanların beden, yürek ve bașı üzerinde çalışılacak enstrümanlardır.

...teknik öğeler bakımından neredeyse her şey sahne sanatlarında olduğu gibidir: Bir şarkı üzerinde, itkiler üzerinde, hareket biçimleri üzerinde çalışırız, metne ilişkin güdüler bile belirir. Bir yapı belirene kadar her şey en temel gereksinimlere indirgenir. Bu, bir gösterimdeki kadar kesin ve ince işlenmiş bir yapıdır, Eylem'dir. (2005, s. 164)

Grotowski 'Araç Olarak Sanat' çalışmasının bütünüyle tiyatronun dışında olmadığını belirtir, hatta bu çalışma tiyatroya ya da onun deyimiyle 'Sunum Olarak Sanat'a katkı sağlamaya namzettir. Çünkü Grotowski'ye göre 'Araç Olarak Sanat' ile 'Sunum olarak Sanat' aynı büyük ailenin iki farklı u cunda yer alırlar ve aralarında "zanaat bilinci üzerinden bir geçit olmalı"dır (2005, s. 180).

Gene de büyük harfle 'Aksiyon' Grotowski açısından bir 'amaç' değil, yapanların kendi gelişimleri üzerinde çalışmalarını sağlayacak bir 'araç’tır. Bu noktada Türkçeye araç olarak çevrilen Grotowskiyen terimin İngilizcede vehicle, yani taşıt ya da vasıta anlamına gelen araç olduğunu belirtmek önemlidir (Grotowski, 1995; 2005). 'Araç Olarak Sanat' yapanların üzerine binip gittikleri bir vasıtadır. Grotowski bunu ilkel bir asansöre benzetir. Bu, 'yapan'ın içinde olduğu ve kendi kendini, bir halatla, gündelik dışı, daha hafif ve hatta yüce olarak nitelenebilecek bir enerji düzlemine doğru çektiği büyük bir sepet gibidir. Amaç yapanın kendi içgüdüsel bedenine inmesidir ve eğer gerçekleştirilen aksiyon görevini yerine getirirse yapan için sepet hareket etmeye başlayacaktır (2005, s. 167-168). Bu hareketi sağlayacak olan şey, söz konusu ilkel asansörü kurabilecek nitelikteki itkilerin açığa çıkarılmasıdır. Bunun yollarından biri geleneksel şarkılar üzerine çalışmaktır. Grotowski çalışmalarında kullandığı geleneksel şarkıların çok önemli bir özelliği olduğunu söyler. Ona göre bu şarkılar organik köklere sahip olan, hiçbir zaman bedene ait yaşayan itkilerden kopuk olmayan şarkılardır. Bu şarkıları "taşıyanlar, beden içinde hareket eden itkiler"dir (2005, s. 172). Bu noktada ilginç bir şekilde karakter fikri geri döner. Grotowski'ye göre yapılacak şey:

Geleneksel şarkının, bağlantılı itkileriyle birlikte 'bir kişi' olduğunu görmektir. ...Çok eski şarkılar vardır, kolayca kadınsı oldukları farkedilir, başka şarkılar da erkeksidir, kimi şarkılarda ergenlik çağındakiler, hatta çocuklar vardır - bunlar da şarkı yaşlılarıdır. ...geleneksel bir şarkı canlı bir varlıktır. Evet, her şarkı bir insan değildir, aynı zamanda hayvan şarkı, güç şarkı da vardır. (2005, s. 171-172) 
Grotowski sanki Stanislavski'nin 'Fiziksel Eylemler Yöntemi'ni şarkı söyleme çalışmasına uyarlamış gibi görünmektedir; burada aranan şey, birer kişi olarak yaklaşılan şarkılara ait organik itkileridir. Grotowski, Stanislavski'nin çalışmasında oyuncu ve karakterin birbirine karışarak nihayetinde üçüncü bir varlığın ortaya çıkmasını anıştıracak şekilde, şarkı söyleme çalışmasında da bir süre sonra şarkıyı söyleyen ile şarkının birbirine geçmeye başlayacağından söz eder: "Titreşimsel nitelikleri yakalamaya başladığımızda bu, itkilerde ve eylemlerde köklenir. Ve ansızın o şarkı bizi söylemeye başlar. O eski şarkı beni söyler. Artık o şarkıyı bulmakta mıyım yoksa ben o şarkı mıyım bilemem" (2005, s. 171). Şarkıyı söyleyen ve şarkı arasındaki ilişki, Stanislavski'nin ya da Brecht'in ortaya koyduğu oyuncu/karakter ikiliğinden farklı bir durumdur. Bunu daha açık bir şekilde kavramak için şarkı söyleme çalışmalarıyla aynı anda yürütülen fiziksel eylemler çalışmasına bakmak yararlı olacaktır. Richards, Grotowski'nin çalışmaya katılanlardan fiziksel eylemlere kaynak olmak üzere kendilerince önemli buldukları kişisel bir anılarını, bir rüyalarını ya da hiç gerçekleşmemiş bir düşlerini kullanmalarını istediğini belirtir ve kendisinin F. isimli bir katılımcıyla yürüttüğü çalışmadan örnek olarak söz eder:

F. adlı genç bir oyuncu vardı. Öykü babasıyla ilgiliydi. Babası bir gece bardan eve sarhoş dönmüş, yere yığılıp sızıncaya değin şarkı söylemişti. ...

F., ...babasının neler yaptığını tam olarak anımsayarak fiziksel davranışın gerçeğe uygun çizgisini oluşturuyordu. Gerçek fiziksel eylemler her zaman arzu ve dileklerle bağlantılı olduğundan, babasının derin arzularını bulmaya da yaklașmıștı. F.nin çalıșmasında onun babasını görmeye bașlamıștım. F.'nin, babasını 'oynayıșını' değil, yalın biçimde babasının eylemlerini yerine getirișini görüyordum. F. üzerinden başka birini görmeye başlamıştım: F. hala oradaydı, ne var ki onun üzerinden bir başkası varlık bulmuştu sanki. (2005, s. 110-111)

F. örneğiyle somutlaşan 'Araç Olarak Sanat' çalışması bir yandan halen tiyatronun içinde olan, öte yandan tiyatroyu aşan bir aksiyon tanımını getirmektedir. Halen bir ikilik - bu örnekte F. ve babası - var gibidir, fakat bu iki öğe arasındaki ilişki bir temsil ya da taklit ilişkisi değildir. F. isimli oyuncu gerçekleştirdiği aksiyonda herhangi bir karakterin ya da teatral konvansiyonun arkasına saklanmamıştır, çünkü F. babasını 'oynamamaktadır'. Yaptığı şey geçmişte tanıklık ettiği babasına ait bir eylemi/aksiyonu hatırlayarak onu şimdi ve burada yeniden gerçekleştirmeye çalışmaktır. Belki de burada aslında ne F.'nin ne de babasının olduğunu söylemek gerekir; şimdi ve burada var olan yalnızca saf aksiyonun kendisidir. F. babasının geçmişteki eylemlerini bugün burada yalın bir şekilde yerine getirirken Grotowski'nin arzu ettiği gibi kendisini aksiyonun içinde unutmuştur. Aslında bu ilişki, Grotowski'nin çalışmalarına katılanlardan kendi kültürlerine ait geleneksel şarkılarla kurmasını istediği ilişkinin aynısıdır. Polonyalı yönetmen şöyle sorar:

[Ş]arkıyı söyleyen kimdir? 0 siz misiniz? Ama bu büyükannenizin şarkılarından biriyse, o hala siz misiniz? Ama eğer siz gövdenizin itkileriyle büyükannenizi arayıp bulmaya çalışıyorsanız, o zaman şarkı söyleyen ne siz ne de büyükannenizdir: büyükannenizi ararken şarkı söyleyen sizsiniz, yani, büyükanne/şarkıcınızı arayıp bulmaya çalışıyorsunuz. Belki birinin bu şarkıyı ilk kez söylediği, hayal edilmesi zor bir zamana ve yere doğru geri gidersiniz. ...eğer şarkının başlangıcına doğru gitme yeteneğiniz varsa, o zaman artık şarkı söyleyen büyükanneniz değildir, ama atalarınızdan, memleketinizden, köyünüzden, anne ve babanızın ve büyükbabanızın köyünden birisidir. (1994d, s. 205-206)

Tıpkı F. gibi büyükannesinin şarkısını söylemeye çalışan kişi için de aslında ne şarkı söyleyen bir büyükanne ne de kendisi vardır. Karakter/oyuncu ikiliği aşılmıștır. Çünkü artık burada ne karakter ne de oyuncu vardır, sadece büyükannesini ya da atalarını ararken şarkı söyleyen -bir kişi olarak değil, fakat bir aksiyon olarakinsan vardır.

Sanat aracılığıyla, saf ya da literal bir aksiyon içinde özgürleşen insana ulaşma düşüncesi her ne kadar Grotowski'nin sanat yaşamının son döneminde olgunlaşmış bir niteliğe bürünmüş olsa da, aslında bu arayış yukarıda da ayrıntılarıyla tartışıldığı gibi onun sanat yaşamı boyunca içinden geçtiği dört dönemin her birinde- 'Gösterim Tiyatrosu' (ya da 'Sunum Olarak Sanat'), 'Para-Tiyatro', 'Kaynaklar Tiyatrosu' ve 'Araç Olarak Sanat' - oldukça önemli bir yer tutmuştur. 


\section{Sonuç}

Temel malzemesi oyuncunun bizzat kendisi olan tiyatro sanatının özü aksiyon(lar) yaratmaktır. Fakat farklı tiyatro yaklaşımları oyuncunun yaratacağı aksiyonun nasıl bir şey olduğu ve ne şekilde oluşturulacağı konusunda değişen düşünceler öne sürmekte ve bunun sonucu olarak birbirinden farklılaşan oyunculuk anlayışları ortaya çıkmaktadır.

Makale boyunca Stanislavski, Brecht ve Grotowski'nin oyuncunun sanatı bağlamında aksiyon kavramına getirdiği yaklaşımlar incelenmiş, bu yaklaşımların hem ortak hem de farklılaşan unsurlara sahip olduğu ortaya konmuş ve sonuç olarak 20. yüzyıl tiyatrosuna damgasını vurmuş olan bu üç tiyatro insanının kendine özgü oyunculuk kuramları geliştirdiği görülmüştür.

Stanislavski, sanat yaşamının son döneminde geliştirdiği 'Fiziksel Aksiyonlar Yöntemi'nde oyuncunun sanatını, içinde olay örgüsü çerçevesinde rolün gerektirdiği birer istek, birer amaç, birer itki taşıyan fiziksel aksiyonları geliştirmek ve bunları anlamlı bir çizgi üstünde bir araya getirerek bir karakter yaratmak olarak tanımlamıştır. Oyuncunun yaşadığı bu psiko-fiziksel süreç içinde temel amaç, canlandırılan karaktere ait aksiyonlara o karakteri iten itkileri keşfetmektir. Stanislavski'ye göre oyuncunun sanatı ancak bu şekilde, oyuncu karaktere ait aksiyonların yapanı/edeni haline geldiğinde doğal ve etkili hale gelecektir.

Brecht, Stanislavski'nin geliștirdiği fiziksel aksiyon çizgisinin keşfedilmesi fikrini reddetmez, ama oyuncunun karakterle özdeşleşmesine şiddetle karşı çıkar. Çünkü ona göre bu durum karakterlerin gerçekleştirdiği aksiyonların seyirci tarafından kaçınılamaz, değiştirilemez gibi görünmesine yol açacaktır. Brecht'in bu olumsuz duruma getirdiği çözüm, oyuncunun bir yandan karakterin aksiyonlarını gerçekleştirirken, bir yandan da bu aksiyonlara karşı kendi tavrını içeren bir ek aksiyon yaratmasıdır. Aynı anda gerçekleşen bu iki farklı aksiyon - karakterin aksiyonu ve oyuncunun aksiyonu - arasındaki diyalektik ilişki, var olan toplumsal yaşamı sorgulayan 'Brechtyen' bir tiyatronun ortaya çıkabilmesini sağlayacaktır.

Öte yandan Grotowski, Stanislavski'nin oyuncunun görevinin itkilerin keşfi aracılığıyla aksiyon(lar) yaratmak olduğu düşüncesini kuvvetle benimser. Fakat onun peşinde olduğu itkiler karaktere ait, oyundaki olay örgüsü içinde şekillenen gündelik hayata ait itkiler değil, oyuncuyu gündelik yaşamın ötesinde bir bütünlük haline taşıyacak özel nitelikteki itkilerdir. Bu anlayış, Grotowski’nin karakter ve onu canlandıran oyuncu ikiliğinden büyük ölçüde uzaklaşmasına ve kişinin neyse o olduğu, ne yapıyorsa onu yaptığı literal aksiyon fikrini geliştirmesine yol açmıştır. Kendisinin daha sonraları 'Araç Olarak Sanat' diye isimlendirdiği bu yaklaşıma göre aksiyon artık sanatsal bir araçtan çok oyuncunun kendi insani gelişimi üzerinde çalışmasını sağlayan yaşama ait bir araç haline gelmiştir.

Stanislavski, fiziksel aksiyonlar geliştirme fikrine dayalı oyunculuk yaklaşımında, karakterin aksiyonlarını oyuncunun aksiyonları haline getirerek karakter ve onu oynayan oyuncu ikiliğini görünmez kılmaya çabalar. Brecht kendi tiyatro anlayışı doğrultusunda, tam tersine bu ikiliği oyuncunun ek aksiyonu fikri aracılığıyla daha da görünür kılmayı hedeflemiştir. Grotowski ise karakter/oyuncu ikiliğinin ötesine geçen saf ya da literal bir aksiyon yaratma fikrinin peşine düşmüştür. Bugün Batı ve Batı dışında oyuncunun sanatına getirilen/getirilebilecek yeni yaklaşımların bu üç etkili tiyatro insanının oyunculuk kuramına getirdiği güçlü düșüncelere olumlu ya da olumsuz bir tepki vermeden olușturulması çok da mümkün görünmemektedir. Bu sebeple onlara ait aksiyon anlayışlarının tüm yönleriyle derinlemesine anlaşılması yeni ortaya çıkan/çıkabilecek oyunculuk yaklaşımlarının anlaşılması açısından oldukça önemlidir.

\section{Kaynakça}

Act. (t.y.a). In Tureng- Turkish English Dictionary. Retrieved from https://tureng.com/tr/turkceingilizce/act

Actor. (t.y.b). In Tureng- Turkish English Dictionary. Retrieved from https://tureng.com/tr/turkceingilizce/actor

Aksiyon. (t.y.). Türk Dil Kurumu Sözlükleri içinde. Erişim adresi: https://sozluk.gov.tr/?kelime=aksiyon

Benedetti, J. (2004). Stanislavski: An introduction. New York: Routledge.

Bentley, E. (2005). Stanislavski ve Brecht (E. Çete, Çev.). Mimesis Tiyatro/Çeviri Araştırma Dergisi, 11, 183190. 
Brecht, B. (2005a). Stanislavski üzerine notlar (E. Çete, Çev.). Mimesis Tiyatro/Çeviri Araştırma Dergisi, 11, 169-182.

Brecht, B. (2005b). Tiyatro için küçük organon (A. Cemal, Çev.). İstanbul: Mitos-Boyut Yayınları.

Carnicke, S. M. (2003). Stanislavsky in focus: An acting master for the twenty-first century. Oxon and New York: Routledge.

Coger, L. I. (2005). Stanislavski fikir değiştiriyor (F. Güllü, Çev.). Mimesis Tiyatro/Çeviri Araştırma Dergisi, $11,163-168$.

Grotowski, J. (1994a). Aksiyon Literal'dir (H. Bahçeci, Çev.). Mimesis Tiyatro/Çeviri Araştırma Dergisi, 5, 171175.

Grotowski, J. (1994b). Bir kaynaklar tiyatrosuna doğru gezinti (Ç. Genç, Çev.). Mimesis Tiyatro/Çeviri Araştırma Dergisi, 5, 177-180.

Grotowski, J. (1994c). Kaynaklar tiyatrosu (Ç. Genç, Çev.). Mimesis Tiyatro/Çeviri Araştırma Dergisi, 5, 185189.

Grotowski, J. (1994d). Sen birinin oğlusun (S. Saral, Çev.). Mimesis Tiyatro/Çeviri Araştırma Dergisi, 5, 195207.

Grotowski, J. (1995). From the theatre company to art as vehicle. In T. Richards, At work with Grotowski on physical actions (p. 115-135) (T. Richards, M. A. Moos and J. Grotowski, Trans.). London: Routledge.

Grotowski, J. (2002). Yoksul tiyatroya doğru (H. Yetişkin, Çev.). İstanbul: Tavanarası Yayıncılı.

Grotowski, J. (2005). Tiyatro Kumpanyası'ndan araç olarak Sanat'a. T. Richards, Grotowski ile fiziksel eylemler üzerine çalışmak (s. 155-180) (H. Yıldız ve A. Candan, Çev.). İstanbul: Norgunk Yayıncılık.

Kolankiewicz, L. (2010). Grotowski mistik bir ustaydı (A. A. Kaim, Çev.). Mimesis Tiyatro/Çeviri Araştırma Dergisi, 17, 89-100.

Moore, S. (2005). Fiziksel aksiyonlar yöntemi (F. Güllü, Çev.). Mimesis Tiyatro/Çeviri Araştırma Dergisi, 11, 159-162.

Mumford, M. (2005). Brecht Stanislavski'yi araştırıyor: Sadece taktik bir hamle mi? (D. Çavdar, C. Tanır ve 0. Uysal, Çev.). Mimesis Tiyatro/Çeviri Araştırma Dergisi, 11, 191-218.

Pavis, P. and Shantz, C. (1999). Action. In Dictionary of the theatre: Terms, concepts, and analysis (p. 9-13). Toronto: University of Toronto Press.

Richards, T. (2005). Grotowski ile fiziksel eylemler üzerine çalışmak (H. Yıldız ve A. Candan, Çev.). İstanbul: Norgunk Yayıncılık.

Schechner, R. (2013). Play. In Performance studies: An introduction (p. 89-122). New York and London: Routledge.

Tanyel, B. ve Esen, U. (1996). Stanislavski ve oyunculuk yöntemi üzerine. Mimesis Tiyatro/Çeviri Araştırma Dergisi, 6, 337-359.

Turner, V. (1982). From ritual to theatre: The human seriousness of play. New York: Theatre Communications Group.

Yaralı, E. ve Karaboğa, K. (2005). Sistem'in kısa tarihçesi. Mimesis Tiyatro/Çeviri Araştırma Dergisi, 11, 117157.

Zarrilli, P. (2013). Introduction: Acting as psychophysical phenomenon and process. In R. Loukes, J. Daboo and P.B. Zarrilli (Ed.), Acting as psychophysical phenomenon and process (p. 1-50), Hampshire and New York: Palgrave MacMillan. 